doi:10.18575/msrs.sm.e.17.04 UDC 664.641:633.12(497.6RS) COBISS.RS-ID 6396952

\title{
Salt Content in White Bread in the Republic of Srpska
}

\section{ABSTRACT}

Introduction: Numerous scientific studies have confirmed that the increased salt intake leads to increased blood pressure and increased risk of cardiovascular diseases. It has been found that the largest salt intake is achieved by eating cereals and their products, including different kinds of bread. The research of nutrition habits of the population of the Republic of Srpska has proven that white bread is most commonly consumed of all cereals.

Aim of the Study: The aim of this study is to determine the salt content in white bread and salt intake assessed by eating white bread, and to indicate the public health importance of regular control of salt in cereals and cereal products.

Patients and Methods: Determining the content of salt in white bread $(n=96)$ was conducted as cross-sectional study, using Mohr's method and specific geographical distribution patterns. Descriptive statistic indicators were used in the survey (the number of samples, minimum and maximum values, standard deviation). $T$ test and Sheffe's post-hoc test were used for testing the significance of differences in salt content in white bread.

Results: The results indicated that there was a statistically significant difference in the content of salt in white bread at the regional level as well as at the level of the region and the Republic of Srpska. The estimated intake of salt by eating white bread clearly pointed to the cardiovascular risk of the population of the Republic of Srpska and confirmed the importance of the public health necessity of the regulations that would ensure continuous monitoring of the salt content in white bread and other cereal products.

Conclusion: Salt intake assessed by eating white bread in population of the Republic of Srpska is bigger than the one in the population of the Republic of Serbia and Portugal. Estimated salt intake by eating white bread can be assessed as high and risky for cardiovascular health. It is necessary to continuously implement and educate the population in the area of proper nutrition.

Keywords: Salt, white bread, cardiovascular diseases

(Scr Med 2017:48:24-29)

\section{Vesna Lazićc}

${ }^{1}$ Public Health Institute of The Republic of Srpska, Regional Center Zvornik

\section{Contact address}

Vesna Lazić

Street Address: Svetog Save 37/a

75400 Zvornik

Republic of Srpska

Bosnia and Herzegovina

e-mail: lazicdrvesna@hotmail.com

phone number: $+387-65-597-291$
Submitted: January $31^{\text {st }}, 2017$ Accepted: February ${ }^{\text {th }}, 2017$

\section{Introduction}

In his original environment, a man had insufficient nutritional intake of salt, and relied on the natural sodium content in food consisting of plants and animals. ${ }^{1}$ The development of food industry and placing on the market large amounts of industrially produced food, has led to 
an increased salt intake. After ingestion, salt dissociates in the digestive tract into sodium and chlorine ion. Absorption of sodium, ingested through food and water, takes place at the level of the small intestine and is about $98 \%$, and similar amount of sodium is excreted from the body via kidneys. ${ }^{1}$ Sodium helps maintain a membrane potential, in the absorption of nutrients from the small intestine, in the implementation of nerve impulses, in the maintenance of extracellular fluid volume and thus has a leading role in maintaining blood pressure. ${ }^{2}$ The World Health Organization (WHO) recommends limiting salt intake to $5.0 \mathrm{~g}$ a day, ${ }^{3}$ while the American Heart Association (American Heart Association, AHA) points out that the patients with hypertension need to reduce salt intake to $3.8 \mathrm{~g}$ a day. ${ }^{4}$

The main food source of sodium is salt, which is used in the production of food for human consumption. Sodium naturally found in food, participates in the total daily intake by 5 to $10 \%$, the amount added during cooking or at the table by 10 to $15 \%$, while sodium/salt from processed foods industry, accounts for about 75 to $80 \% .^{5}$ The main sources of salt in the diet are bread and rolls, followed by meat and meat products, cheese, canned vegetables and dehydrated soups. ${ }^{6,7}$

Hypertension, cardiovascular (CVD) and cerebrovascular diseases are a global public health problem and the most frequent causes of death. In the Republic of Srpska, cardiovascular diseases in 2014 participated with $47 \%$ in causes of total mortality, while for the same year, the mortality due to neoplasms was $21.9 \% .^{8}$ Although mass noncommunicable diseases (MND) affect mainly adult population, there is a great increase of the risk of their occurrence in children. ${ }^{9}$ WHO points out that reducing salt intake to the recommended value of $5 \mathrm{~g}$ per day leads to the reduction of the risk of cardiovascular diseases by $17 \%$ and stroke by $23 \% .5,10$ Hypertension is the leading cause of MND. The prevalence of hypertension in many European countries is more than 40\%, especially in those countries where the large population salt intake was found. ${ }^{11-15}$ In the Republic of Srpska, salt used in diet is an important source of iodine.

Bread is the basic food from the grain group and the production of bread includes a specific type of flour, yeast, salt and water as basic raw materials.

Based on the analysed data in the Report on the results of studies of health of the Republic of Srpska population from 2010, the adult population of the Republic of Srpska uses white and semi-white bread in diet more often. ${ }^{13}$

\section{Aim of the Study}

Determining the salt content in white bread, determining the amount of salt according to Mohr's method and evaluating salt intake by measuring white bread consumption of the adult population aged from 18 to 65 . Raising awareness about the public health importance of regular controls of salt content in cereals and cereal products.

\section{Patients and Methods}

The survey was conducted as a cross-sectional study, in the period from January $20^{\text {th }} 2016$, to March $9^{\text {th }} 2016$. The survey included manufacturers of white bread on the territory of the Republic of Srpska that are subject to regular safety surveillance, in accordance to the Food Law of the Republic of Srpska (Food Law, Official Gazette of the Republic of Srpska No. 49/o9). The study involved Public Health Institute Banja Luka and five Regional centers in Doboj, Zvornik, East Sarajevo, Trebinje and Foca.

The collection of samples was carried out in accordance with the sampling plan of the Department of Hygiene, the Institute for Public Health and the Section of Hygiene from the regional centre. The subject of sampling was white bread, made of "type 500" flour.

Testing of salt content was performed according to Mohr's method and the principle of precipitation titration, in the Department of Sanitary Chemistry Institute for Public Health and in the laboratories for hygienic and microbiological analyses in regional centers.

After laboratory analyses, reports on the results of tests of salt content in white bread were delivered to the reception area of the Service or to the Department of Hygiene, where they were taken over after the research was completed.

Data processing and statistical analysis were conducted in the program SPSS 20. Statistical analysis determined the following data: number of samples (n), the minimum value (Min), the maximum value (Max) and average value $(\mathrm{X})$, standard deviation (SD) and the coefficient of variation (CV). T-test was used for comparison of the groups. Scheffe's post-hoc test was used to test the significance of multiple comparisons.

\section{Results}

The study included 88 subjects from the Republic of Srpska with 96 samples of white bread (90 unpackaged and 6 bulk packaged products). Interpretation of the results was conducted in accordance with the geographical 
distribution of the samples from three regions. The first region of the distribution of the sample consisted of the cities of Banja Luka and Prijedor and municipalities of Gradiška, Kotor Varoš, Kostajnica, Mrkonjić Grad, Novi Grad, Prnjavor and Srbac, with the total participation of 50 samples in the research. The second region included the cities of Bijeljina, Doboj and Zvornik, municipalities of Bratunac, Brod, Derventa, Modrica, Ugljevik, Modriča, Teslić and Vlasenica, with the total participation of 33 samples in the research. The third region encompassed the cities of East Sarajevo and Trebinje, municipalities of Han Pijesak, Foca, Ljubinje, Nevesinje and Pale, with the total participation of 13 samples in the research. Results of salt content in white bread obtained by applying Mohr's method are shown in Table 1.

Table 1. Results of the Salt Content of White Bread Obtained by The Mohr'S Method (g of Salt in $100 \mathrm{~g}$ of a Product)

\begin{tabular}{cccccc}
$\begin{array}{c}\text { Observation } \\
\text { unit }\end{array}$ & $\begin{array}{c}\text { Number } \\
(\mathrm{n})\end{array}$ & Min & Max & X & SD \\
\hline Region 1 & 50 & 1.18 & 2.12 & 1.51 & 0.227 \\
Region 2 & 33 & 1.10 & 2.40 & 1.77 & 0.310 \\
Region 3 & 13 & 1.25 & 2.06 & 1.50 & 0.223 \\
$\begin{array}{c}\text { Republic of } \\
\text { Srpska }\end{array}$ & 96 & 1.10 & 2.40 & 1.60 & 0.286 \\
\hline
\end{tabular}

Legend: Min-minimal value, Max-maximal value, $X$-average value, $S D$-standard deviation

A The analysis of the salt content in white bread was carried out on 96 samples. Based on these results, it was found that the content of salt in white bread ranged from $1.10 \mathrm{~g}$ to $2.40 \mathrm{~g}(\mathrm{X}=1.60, \mathrm{SD}=0.286)$ for the Republic of Srpska. The minimum and maximum values of the salt content in white bread were recorded in Region 2. Given that for each of the regions, values of salt content in white bread were separately grouped, it was found that they were slightly higher in the bread from the Region 2 ( $X=$ 1.77, $\mathrm{SD}=0.310)$ compared to the bread from the Region $1(\mathrm{X}=1.51, \mathrm{SD}=0.226)$ and bread from the Region $3(\mathrm{X}=$ $1.50, \mathrm{SD}=0.223)$. Upon testing the statistical significance of these differences, it was found that the obtained value of $\mathrm{F}=11.68 \mathrm{odf}=2$ exceeded the threshold for significance at the 0.01 level, and the conclusion was that at least one of three possible differences was statistically significant.

Scheffe's post-hoc test showed that the analysis of the obtained salt content in white bread from the Region 2 was statistically significantly different from the values obtained in Region 1 ( $\mathrm{p}=0.000, \mathrm{p}<\mathrm{0.01})$ and Region 3 $(\mathrm{p}=0.006, \mathrm{p}<0.01)$.
Upon the analysis of statistical significance and the differences in the average salt content in bread for the Republic of Srpska and some regions, the existence of statistical significance of differences in salt content for Region 1 and Region 2 was found (Table 2 - 4).

The average salt content in white bread on the territory of the Republic of Srpska was higher $(\mathrm{X}=1.60, \mathrm{SD}=0.286)$ than the salt content in white bread from Region 1 ( $\mathrm{X}=$ $1.51, \mathrm{SD}=0.227)$. Upon statistical significance testing, it was observed that these differences were statistically significant $(\mathrm{t}=-2.780, \mathrm{p}=0.008, \mathrm{p}<0.01, \mathrm{df}=49)$; Table 2.

Table 2. Results of T-test for Region 1

\begin{tabular}{ccc}
\hline X & $\begin{array}{c}\text { The Republic } \\
\text { of Srpska }\end{array}$ & Region 1 \\
SD & 1.60 & 1.51 \\
\hline Min & 0.286 & 0.227 \\
Max & 1.10 & 1.18 \\
N & 2.40 & 2.12 \\
t test & 96 & 50 \\
\hline
\end{tabular}

Contrary to Region 1, the values of salt content in white bread determined from Region 2 were significantly higher $(\mathrm{X}=1.77, \mathrm{SD}=0.310)$, compared to the average value determined for the content of salt in white bread for the Republic of Srpska (X = 1.60, SD = 0.286). After testing the statistical significance of the differences, it was observed that these differences were statistically significant $(t=3.270, p=0.003, p<0.01, d f=32)$; Table 3 .

Table 3. Results of T-test for Region 2

\begin{tabular}{ccc} 
X & $\begin{array}{c}\text { The Republic } \\
\text { of Srpska }\end{array}$ & Region 2 \\
SD & 1.60 & 1.77 \\
Min & 0.286 & 0.310 \\
Max & 1.10 & 1.10 \\
N & 2.40 & 2.40 \\
t test & 96 & 33 \\
\hline
\end{tabular}


Although the average value of the salt content in white bread, on the territory of the Republic of Srpska (X = $1.60, \mathrm{SD}=0.286$ ) was slightly higher compared to the established value of the salt content in white bread from Region 3 (X $=1.50, \mathrm{SD}=0.223)$, it was observed that the difference was not statistically significant $(\mathrm{t}=-1.616, \mathrm{p}=$ 0.132, $\mathrm{p}>0.05, \mathrm{df}=12$ ); Table 4 .

Table 4. Results of t-test for Region 3

\begin{tabular}{ccc} 
X & $\begin{array}{c}\text { The Republic } \\
\text { of Srpska }\end{array}$ & Region 3 \\
SD & 1.60 & 1.50 \\
Min & 0.286 & 0.223 \\
Max & 1.10 & 1.25 \\
N & 2.40 & 2.06 \\
t test & 96 & 13 \\
\hline
\end{tabular}

Based on the national survey in the Republic of Srpska, it was determined that, of all cereals, the adult population ( $\geq 18$ years old to 65 years old) most commonly consumed white bread (89.5\%), and they ate 4,8 slices of bread daily. The quantity of white bread eaten by an adult resident of the Republic of Srpska amounted to $2.30 \mathrm{~g}$, and respectively for such a resident of Region 1, this amount was $2.16 \mathrm{~g}$, for Region 2 it was $2.54 \mathrm{~g}$ and for Region 3 it was $2.16 \mathrm{~g}$. The standard ration for a slice of bread was used, and according to the recommendations of the US Department of agriculture (United States Department of agriculture, USDA Food Guide) in 2010 it amounted to $30 \mathrm{~g}$.

The average salt intake by white bread consumption was compared to the recommendations for salt intake given by world authorities. In relation to the recommendations of the WHO, the average intake of salt by white bread consumption in this study was $46.0 \%$ (at the regional level it ranged from 43.2 to 50.8\%). Using AHA recommendations, it was found that the average salt intake in the study was $60.5 \%$ (at the regional level it ranged from 56.8 to $66.8 \%$ ) of the recommended values.

\section{Discussion}

In the Republic of Srpska there is no legal act which regulates the amount of salt in bread and bakery products, hence it is rather left to the will of manufacturers.

According to this research, the residents of the Republic of Srpska, when consuming $100 \mathrm{~g}$ of white bread, averagely intake $1,60 \mathrm{~g}$ of salt $(\mathrm{SD}=0,286)$ and $0.48 \mathrm{~g}$ of salt when consuming standard serving of white bread measuring $30 \mathrm{~g}$. Looking at the results of the research by region, it can be noticed that the residents of Region 2 take the highest intake of salt by consuming white bread $(X=1.77, S D=0.312)$. By analyzing the statistical significance of differences of salt content in white bread from the regions and in the total sample for the Republic of Srpska, using t-test, a statistically significant difference in the comparison of data for the Republic of Srpska and Region $1(\mathrm{p}=0.008, \mathrm{p}<0.01)($ Table 2$)$ and Region $2,(\mathrm{p}=$ o.003, p <0.01) (Table 3), was found, while the difference determined for Region 3 was not statistically significant ( $\mathrm{p}=0.132, \mathrm{p}>0.05$ ) (Table 4).

If we compare this data to the data of the researchers who have used the same method of analysis in the Republic of Serbia, it can be concluded that the salt content identified in this study was higher by $0.39 \mathrm{~g}$. However, it should be noted that in this study, white bread was not separated as a separate product group. The sampling lasted 8 years. Also, the analysis method was changed in the course of research in the potentiometric titration. By comparing the results of both methods, the researchers found that the difference in terms of results was negligible, and both methods could be considered precise. ${ }^{14}$

If we compare this data to the data of the researchers from Portugal, who determined sodium by flame photometry on 408 samples of white bread in 2006 , it can be seen that the average value is $534 \mathrm{mg}$ per $100 \mathrm{~g}$ of product with a range of concentrations from 344 to $718 \mathrm{mg}$. During the conversion of the quantity of sodium into the salt, the formula $\mathrm{Na}(\mathrm{g}) \times 2.5=\mathrm{NaCl}(\mathrm{g})(0.534 \times 2.5=1.33 \mathrm{~g})$ was used, and it was concluded that the average value of the salt in the white bread from Portugal researchers was lower for $0.27 \mathrm{~g}$ than our results. However, it should be noted that their method of analysis differs from the method of this research. ${ }^{15}$

Through epidemiological data on the intake of bread, it was found that, only by eating bread, the population of the Republic of Srpska intakes nearly half of daily intake of salt recommended by $\mathrm{WHO}^{3}$, and three-fifths of the value compared to the recommendations given by AHA. ${ }^{4}$ It should be noted that this was only white bread consumption and the intake of salt or sodium from all other sources was not considered. Since epidemiological studies have shown that every tenth inhabitant adds salt in food at the table and almost every second inhabitant twice a week eats dry meat products that contain two sources of sodium (from salt and preservatives sodium benzoate), it can be said that the population of the Republic of Srpska is at risk of developing CVD.

Even though the natural sodium content in food is 
sufficient to maintain physiological needs of organism,,$^{1,2}$ research on a population salt taking ${ }^{5,10}$ confirm that the intake is far above the recommended daily values., ${ }^{3,6}$

Numerous studies have shown that high salt intake has a role in the development of high blood pressure ${ }^{3,11}$ and thus less salt intake leads to the reduction of blood pressure..$^{16}$ The conclusion is that a balanced diet with the special emphasis on the amount of salt, and physical activity are key to reducing morbidity from hypertension. ${ }^{12}$

Key activity for the reduction of salt intake proposed by the WHO is the development of legislation that would allow the placing on the market of food with lower salt content. ${ }^{3.5}$ Knowing that white bread is the food that the population of the Republic of Srpska daily consume, ${ }^{13}$ reducing salt intake in this type of cereal products would result in total reduction of salt intake on a population level ${ }^{5,11}$ and, consequently, would decrease morbidity from hypertension, ${ }^{16}$ cardiovascular and cerebrovascular deseases. ${ }^{8}$ For these reasons, the amount of salt not only in white bread, but also in other food products is public health problem that is preventable. The health system of the Republic of Srpska is burdened by treatment of MND, which is preventable, and therefore the reduction of population salt intake has a great significance in terms of cardiovascular health.

Reducing salt intake to the recommended value suggested by $\mathrm{SZO}^{3}$ or $\mathrm{AHA},{ }^{4}$ leads to reduced amount of iodine inserted into the body (100-150 $\mu \mathrm{g}$ of iodine in the event of WHO recommendations and 76-114 $\mu$ g iodine in the case of recommendations AHA). Research in 2010 showed that residents of the Republic of Srpska eat fish rich in iodine only once a week or more rarely. ${ }^{13}$

In order to avoid the return of endemic goiter, it is necessary, along with education of the population on the amount of salt that is recommended by world authorities, to simultaneously educate people about the selection of food rich in iodine.

A balanced diet together with physical activity is the life style in which the risk of these factors is reduced to a minimum.

\section{Conclusion}

Values of salt content in white bread were in the range of $1.10 \mathrm{~g}$ to $2.40 \mathrm{~g}$ in $100 \mathrm{~g}$ of the product, and the highest value was obtained in Region 2 (1.77 g). Statistically significant differences in the content of salt in white bread between the Regions and the Region and the Republic of Srpska were found.
Residents of the Republic of Srpska consume $0.39 \mathrm{~g}$ per $100 \mathrm{~g}$ salt in white bread more than the population of the Republic of Serbia, and $0.27 \mathrm{~g}$ per $100 \mathrm{~g}$ salt more than the population of Portugal. On the basis of epidemiological data on the intake of white bread, salt intake estimated through this type of cereal in this study ranged up to three-quarters of the recommended daily salt intake proposed by world authorities. Estimated intake of salt by consuming white bread can be marked as high risk factor for the cardiovascular health problems of the residents of the Republic of Srpska aged from 18 to 65 . The results clearly indicate that, in order to prevent the return of endemic goiter to our area, it is necessary to continuously educate the population regarding proper nutrition, which includes the reduction of salt intake, and the increase of the intake of food that is rich in iodine.

Reducing the amount of salt in bread and educating people about proper nutrition with an emphasis on reducing salt intake could lead to reduction in salt intake in population, which would be reflected in the reduction of the prevalence of hypertension and cardiovascular and cerebrovascular diseases.

\section{References}

1. Food and Nutrition Board, Institute of Medicine, United States National Academies. Dietary Reference Intakes: Water, Potassium, Sodium, Chloride, and Sulfate. 2005. Available on: http://www.nap.edu/read/10925/chapter/8

2. Guyton AC, Hall JE editors. Textbook of Medical Physiology. Philadelphia, Pennsylvania. Elsevier Saunders. 2006. Available on http://vet.uokufa.edu.iq/staff/falah/ Textbook\%20of\%20Medical\%2oPhysiology. pdf

3. World Health Organization. Guidelines: Sodium intake in adults and children. Geneva. 2012. Available on: http:// www.who.int/nutrition/publications/guidelines/sodium _ intake/en/

4. Eckel RH, Jakicic JM, Ard JD et al. 2013 AHA/ACC guideline on lifestyle management to reduce cardiovascular risk: a report of the American College of Cardiology/American Heart Association Task Force on Practice Guidelines. J Am Coll Cardiol 2014;63:2960-84. Available on: http:// content.onlinejacc.org/article.aspx?articleid=1770218

5. World Health Organisation. Regional office for Europe. Mapping salt reduction initiatives in the WHO European Region. 2013. Available on: http://www.euro.who. int/__data/assets/pdf_file/ooo9/186462/Mapping-saltreduction-initiatives-in-the-WHO-European-Region.pdf

6. Scientific Advisory Committee on Nutrition (SACN). Salt and Health. The Stationery Office, London. 2003. ISBN 011 243075 9. Available on: https://www.gov.uk/government/ uploads/system/uploads/attachment_data/file/338782/ SACN_Salt_and_Health_report.pdf

7. Ni Mhurchu C, Capelin C, Dunford EK, Webster JL, Neal 
BC, Jebb SA. Sodium content of processed foods in the United Kingdom: analysis of 44,00o foods purchased by 21,00o households. The American Journal of Clinical Nutrition. 2011;93(3):594-600.

Available on: http://www.ncbi.nlm.nih.gov/pmc/articles/ PMC3561609/ https://doi.org/10.3945/ajcn.110.004481

8. JZU Institut za javno zdravstvo Republike Srpske. Zdravstveno stanje stanovništva Republike Srpske. 2014. Dostupno na: http://www.phi.rs.ba/pdf/publikacije/ publikacija_zdr_stanje_2014.pdf

9. He FJ, Marrero NM, MacGregor GA. Salt and blood pressure in children and adolescents. J Hum Hypertens. 2008 Jan;22(1):4-11. Epub 2007 Sep 6. Available on: http://www.ncbi.nlm.nih.gov/pubmed/17823599

10. James AP, Oparil S, Carte BL et al. Evidence Based Guideline for the Management of High Blood Pressure in Adults. Report From the Panel Members Appointed to the 8th Joint National Committee (JNC8). JAMA. doi:10.1001/ jama. 2013. 284427 Published on line December 18,2013. Available on: http://jama.jamanetwork.com/article. aspx? articleid $=1791497$

11. European Commission. Implementation of the EU Salt Reduction Framework Results of Member States survey. 2012. Available on: http://ec.europa.eu/health/nutrition_ physical_activity/docs/salt_report_en.pdf
12. Kotchen TA, Kotchen JM. Nutrition, Diet, and Hypertension. In: Shils ME. et al. Modern nutrition in Health and Disease, 1oth Ed., Philadelphia, Lippincott Williams \& Wilkins, 2010; 1095-1107

13. Matović-Miljanović M, Grozdanov J, Božanić V i et al. Istraživanje zdravlja stanovništva Republike Srpske. Izveštaj o rezultatima istraživanja. 2012.

14. Vieira E, Oliveira BMPM, Soares ME et al. Estudo do teor de sódio em pão consumido no Porto. Alimentação Humana. 2007;13:97-103. Available on: http://www. spcna.pt/download.php?path $=$ pdfs \&filename $=\mathrm{R}$ EV_2007_3_97-103_RAH_2007_n_3_5.pdf

15. Trajković Pavlović Lj, Popović M, Bijelović S, Velicki R, Torović LJ. Salt Content in Ready-to-Eat Food and Bottled Spring and Mineral Water Retailed in Novi Sad. Srp Arh Celok Lek. 2015 May-Jun;143(5-6):362-368. Available on: http://www.doiserbia.nb.rs/img/doi/o3708179/2015/0370-81791506362T.pdf

16. Sacks FM, Svetkey LP, Vollmer WM et al. Effects on blood pressure of reduced dietary sodium and the Dietary Approaches to Stop Hypertension (DASH) diet. DASH Sodium Collaborative Research Group. N Engl J Med 2001;344:3-10. Available on: http://www.nejm.org/doi/ full/10.1056/NEJM200101043440101 https://doi.org/10.1056/NEJM200101043440101

\section{Sadržaj soli u bijelom hljebu u Republici Srpskoj}

\section{SADRŽAJ}

Uvod: Brojne naučne studije su potvrdile da povećan unos soli hranom dovodi do povećanja krvnog pritiska i rizika od kardiovaskularnih bolesti. Utvrđeno je da se najveći unos soli postiže konzumiranjem žitarica i njihovih proizvoda, uključujući različite vrste hljeba. Istraživanjem životnih navika u ishrani stanovništva Republike Srpske dokazano je da se od namirnica iz grupe žitarica najčešće konzumira bijeli hljeb.

Cilj rada: Ciljevi rada su utvrditi sadržaj soli u bijelom hljebu, procijeniti unos soli putem bijelog hljeba i ukazati na javnozdravstveni značaj redovne kontrole soli u namirnicama iz grupe žitarica i proizvoda od žitarica.

Ispitanici i metode: Utvrđivanje sadržaja soli u bijelom hljebu $(n=96)$ sprovedeno je kao studija presjeka, metodom po Moru (Mohr) i posebnom geografskom distribucijom uzoraka. Korišteni su pokazatelji deskriptivne statistike u istraživanju (broj uzoraka, minimalne i maksimalne vrijednosti, standardna devijacija). Za testiranje značajnosti razlike sadržaja soli u bijelom hljebu korišten je t test i Sheffeov post hoc test.

Rezultati: Rezultati ukazuju da postoji statistički značajna razlika u sadržaju soli u bijelom hljebu na nivou Regije, kao i na nivou između Regija u Republici Srpskoj. Procijenjen unos soli putem bijelog hljeba nedvosmisleno ukazuje na rizik u pogledu kardiovaskularnog zdravlja stanovnika Republike Srpske, te potvrđuje javnozdravstveni značaj potrebe za regulativom koja će obezbjediti kontinuirani monitoring nad sadržajem soli u bijelom hljebu i ostalim proizvodima od žitarica.

Zaključak: Stanovnici Republike Srpske unose više soli putem bijelog hljeba od stanovnika Srbije i Portugalije. Procijenjeni unos soli putem bijelog hljeba može se ocijeniti kao visok i rizičan po kardiovaskularno zdravlje. Neophodno je kontunirano provoditi i edukaciju stanovništva u oblasti pravilne ishrane.

Ključne reči: So, bijeli hljeb, kardiovaskularne bolesti 